Religion, State \& Society, Vol. 28, No. 4, 2000

\title{
Nationalism and Religious Protest: The Case of the National Day Celebration Service Controversy in the Hong Kong Protestant Churches
}

\author{
SHUN-HING CHAN
}

\section{Introduction}

The relationship between the government of the People's Republic of China and Hong Kong society since the return of the former British colony to the Mainland has become an important subject for sociological study. The Chinese government made a major effort to promote nationalism in Hong Kong during the transitional period before reunification, emphasising correct 'patriotic' ideas and attitudes. Most visibly, a variety of campaigns celebrating the reunification were organised by different sectors of Hong Kong society from late 1996 until mid-1997, which were endorsed or otherwise encouraged by the Chinese government. Even before the handover, while trying to foster a joyous mood in Hong Kong society, the Beijing government was also attempting to demonstrate its sovereignty over the territory. While most individuals and social groups in Hong Kong were largely indifferent to these celebrations, some social groups organised 'anti-celebration' activities to counteract the message the Chinese government was trying to convey.'

In 1996 many Hong Kong Protestant churches were engaged in a debate over how to celebrate the reunification. A proposal was made by 47 church leaders to host a National Day Celebration Service on 1 October 1996 (hereafter referred to as the 'proposed service'). It sparked a heated debate among the Protestant communities that lasted for more than six months. Rather unusually, the controversy arising from the proposed service (hereafter referred to as the 'controversy') was widely reported in the Hong Kong media. Detailed coverage featured forums with articles contributed by both supporters and critics of the proposed service. Newspapers and journals that reported on the controversy include the Ming Pao Daily, the Hong Kong Economic Journal, the South China Morning Post, Sing Tao Daily, Newsweek, the Asian Wall Street Journal, the Far Eastern Economic Review, and The Nineties. ${ }^{2}$ The Christian Times, a Protestant weekly newspaper in Hong Kong, provided updated reports on the controversy and became a battlefield for the debate. Given the scope of coverage by local and international media, the controversy could justifiably be regarded as a social incident rather than merely an internal religious dispute. Protestant church members in the former British colony expressed how they perceived and felt about reunification. These expressions were in fact an indication of their political positions in relation to and opinion of the Chinese government. The controversy was also a reflection on the interaction between politics and religion in Hong Kong. 
The controversy has relevant theoretical implications on the role of the Christian religion in a civil society and the transition to democracy. Scholars have sought to investigate how the Christian faith and the churches' mobilising powers have contributed to the building of a civil society and the transition to democracy. ${ }^{3}$ Attempts to apply the civil society concept to China have also become increasingly popular following the Tiananmen pro-democracy incident in $1989 .{ }^{4}$ Craig Calhoun, in particular, has critically discussed the concept of a civil society in China in recent years. He has also put forth some inspiring reflections on the role of religion in the construction of a civil society. According to Calhoun, ${ }^{5}$ a civil society is a political community independent of state power whose formation is driven by the people's voluntary collective action. For a national state, the basis of solidarity among members rests largely on cultural similarities and common ancestral origins. The conflict between nationalism and the idea of a civil society lies in nationalism's emphasis on the monopolistic nature of the nation and the denial of the diversity of its members and their rights to democracy and self-determination. In a civil society, members seek to reach rational agreements, develop communal identities and establish bases for integration through rational-critical discourses on political issues, which are conducted in the public domain and evaluated on the basis of 'better' arguments. The process of rational-critical discourse helps to enhance democratic inclusiveness, whereby diversity is acknowledged in the civil society. The construction of a civil society therefore shows characteristics similar to those of the identity politics' of the 'new social movements'. The importance of the civil society theory for procuring social change is underpinned by the fostering of civil power against the dominance of state power through public discourse and the process of constructing a civil society, as well as the highlighting of social foundations for the transition to democracy. As such, this theory is also very promising in providing new insights for China studies. Calhoun's discussions referred to above can be used as a conceptual framework for an in-depth case study of the controversy.

The purpose of this paper is to examine the factors contributing to the emergence and development of the controversy from the perspective of Calhoun's civil society theory, and to investigate its positive implications for the building of a civil society. The present scope of study includes the debates, claims, actions and consequences of the controversy that took place during the period May-October 1996. This paper adopts a qualitative approach via case study, and materials cited are based to a great extent on interviews and articles published in newspapers and journals as well as on observations made during personal participation in related activities. I argue that the proposed service was a political protest in the ideological sphere launched by the Hong Kong Protestant community in response to China's official call to uphold nationalism during the reunification period. At the same time, it can also be understood as an active and conscious political act by a civil society in Hong Kong to counteract the power of state ideological control. The controversy itself has profound historical and social implications from the perspective of the theory of what constitutes a civil society, regardless of its eventual outcome. While providing a realistic case for evaluating the civil society theory, the controversy also offers exemplary insights into the long-term building of a civil society in Hong Kong.

\section{Analysis of the Controversy}

The local Protestant community itself has produced a variety of interpretations of the controversy. ${ }^{6} \mathrm{I}$ hold the view that the proposed service represents an attempt by 
certain church leaders (hereafter referred to as the 'sponsors') to persuade the entire Protestant community to support a collective politico-religious action in response to Beijing's call to uphold nationalism. The sponsors believed that churches and Christian schools should establish their own 'non-official' National Day celebration in 1996 to avoid being obliged by the Chinese government to take part in official celebrations after 1997. ' The sponsors also planned to redefine the meaning of the National Day from a Christian perspective. In other words, they were proposing an 'alternative National Day celebration'. ${ }^{8}$ The proposal was met with harsh criticism from within the Protestant community. In the six months that followed, the sponsors were engaged in intense debate with their opponents in newspapers and at meetings and forums. Church leaders, theologians, clergy, members of Christian social groups and lay believers all took part in the debate. Open forums were organised to discuss the issue and attendance varied from about 100 to 700 participants. ${ }^{9}$ In contrast, the proposed service itself, eventually held on 1 October 1996, was attended by only about 120 people. ${ }^{10}$ A year later, in 1997, it was attended by fewer than 30 people." Given the small attendance and its lack of legitimacy within the Protestant community, the collective politico-religious action engineered by the sponsors seemed less than successful.

The best outcome of the controversy, in the light of Calhoun's theory, would have been if the sponsors and their opponents had been able to carry out discussions on the collective politico-religious action on a basis of equality, if they had been able to provide good arguments and eventually reach a consensus after rational-critical discourse, and if during this process a common identity had gradually emerged and the collective action had been implemented as agreed. The rational-critical discourse and collective action of the Protestant community would then have become an example for other social groups to follow, encouraging them to join hands in promoting a civil society in Hong Kong.

In reality, of course, the Protestant community failed to achieve any collective action. I believe that the idea of the proposed service itself was not necessarily responsible for its failure. In other words, there might have been other outcomes. The fact that the proposed service failed to win approval within the Protestant community and effectively mobilise its members requires further in-depth investigation. The controversy, emerging in the way it did and ending with the results it did, was a dynamic social process driven by the interaction of different factors. Factors such as the sponsors' mobilisation strategy, their arguments and their replies to criticisms, as well as their opponents' understanding of the proposed service and their counterarguments, were crucial to the outcome of the intended collective action. The following is an attempt to interpret and reconstruct the controversy from its emergence to its final outcome and to investigate the structural factors underlying the failure of the sponsors to mobilise the religious community to take part in a collective action.

\section{The Idea of the Proposed Service}

Discussions relating to the hosting of the proposed service started among certain Protestant leaders in November 1995.'2 By March 1996 there were 14 core members. A private forum was held on 28 March 1996 to discuss the idea and church leaders attending the forum were also invited to be sponsors of the event. The letter of invitation proposed that two open forums should be held, one for clergy in May and the other for lay members in June, and that there should be a 'National Day Celebra- 
tion Meeting to pray for the country' on 29 September. The letter specifically noted 'that there is no hidden agenda and that all we are looking forward to is a frank discussion for the benefit of more insight' ${ }^{13}$ After the private forum had taken place the number of sponsors increased to 47. On 8 May 1996 the Ming Pao Daily reported on the debate within the Protestant churches on whether they should nominate representatives to join the Selection Committee for the chief executive and provisional legislators of the Hong Kong Special Administrative Region (SAR) under the headline 'Protestant leaders split over involvement in politics: Lo involved in Selection Committee while Chu held on to principles' ('Jidu jiaopai shezheng dafenqi: Lu Longguang gao tuiwei, Zhu Yaoming shou yuanze'). The church leaders' plan for making preparations for the proposed service was also disclosed in another section of the same report, which occupied the lower half of the day's front page, ${ }^{14}$ and this immediately aroused concern among a variety of groups in Hong Kong society as well as the Protestant community. ${ }^{15}$

In April 1996 the sponsors announced that two open forums would be held entitled 'Road to Reunification'. The invitations were signed by the 47 church leaders. The first forum, to be held on 24 May 1996, was for clergy and church workers. The second forum was to be held on 30 June, this time for lay members. The wording of the invitation letter was nearly the same as the one for the private forum mentioned above, except that it specifically stated that the National Day celebration activities, proposed to be held on 29 September, would proceed only with the support of participants at the forums on 24 May and 30 June. ${ }^{16}$ The arrangement indicates that the sponsors were seeking to persuade the clergy and lay members, in separate meetings, to support the proposed service. Their purpose was to mobilise members of the religious community to take part in a non-official 'alternative National Day celebration'.

In the run-up to the first 'Road to Reunification' forum, Raymond Fung started to explain the idea in detail in the Christian Times in order to solicit support from the wider Protestant community. Fung, a veteran local theologian, was formerly secretary for mission at the World Council of Churches. He took it for granted that Christians should be patriotic, therefore the issue at stake was not whether one should be patriotic, but rather the manner in which patriotism should be expressed. According to Fung:

With Hong Kong becoming a Special Administrative Region (SAR) of China after 1997, the expression of patriotism is a new agenda that Christians must face. How should the churches express patriotism as a religious community and as a social group? This is a challenge we cannot evade. Christians and the churches in Hong Kong have always been patriotic ... it is only reasonable to request that this patriotic feeling be outwardly expressed." 17

The legitimate promotion of any idea or activity in the Christian community usually requires a sound religious or theological basis. Fung resorted to a 'priesthood theology' in order to justify the alternative National Day celebration and the proposed service. According to Fung, the concept of 'China' meant more than a communist regime and the Christian community 'has every right to claim China for their own'.

The church should fulfil its priestly duties and petition to God on behalf of the nation. The priest raises the cup of thanksgiving to God, not to the 
political regime. He offers repentance, intercession and joyous thanksgiving on behalf of the nation rather than singing the praises of the regime in power. The church, in its priestly role, declares in front of God and the people that the nation is no captive of the ruling regime. ${ }^{18}$

The declaration that 'the nation is no captive of the ruling regime' underlies the sponsors' intention to redefine the meaning of the National Day celebration from a religious perspective, deliberately emphasising that the focus of the celebration should be the nation and minimising the role of the communist regime. In another article Fung pointed out that ' 1 October is celebrated as the National Day, not the Party Day. It was the Chinese people, not the communists, that Mao Zedong declared on that day to have arisen from weakness and humiliation.' ${ }^{19}$

Fung also elaborated on the social implications of the proposed service. He believed that holding a service on National Day would 'depoliticise' the event and offer an alternative approach for celebration.

The idea being advanced is that of promoting Christian reflection on the meaning of celebrating the National Day. This is not in the least intended to be 'exclusive'. The church's celebration is based on its religious understanding. It is bound to be different, but it does not claim to be superior or exclusive. ${ }^{20}$

Referring to the New China News Agency (NCNA), Fung maintained that 'after performing our obligations to God, we can also perform our obligations to others. For example, officials from the NCNA can be invited to attend. The important thing is that this is a Christian event in which we [the church] are the host and others are guests. ${ }^{21}$ This shows that the sponsors hoped to free the church from possible manipulation by the NCNA.

\section{The First Mobilisation for the Proposed Service}

More than 250 clergy and church workers attended the first 'Road to Reunification' forum and leaders from various churches were asked to speak. ${ }^{22}$ The arrangements reflected the 'institutional culture' of the Protestant Churches as well as the mobilisation strategy of the sponsors. With the support of reputed church leaders, the sponsors hoped to win recognition for the proposed service and mobilise clergy from different churches. While explaining the purpose of the proposed service, most of the church leaders at the forum also expressed their personal national sentiments. Lo Lung Kwong, for example, issued a challenge: should the church accept growing restraint on Christian activities or should it fight to maintain an independent status? 'I want to celebrate the National Day too. If they [the Chinese government] have their interpretation, do we not have ours? Do we not have our way of celebration?' ${ }^{23}$ Carver $\mathrm{Yu}$, another speaker, said that regimes would come and go, but that the history of national liberation should not be forgotten. He believed that expressing solidarity with the nation by celebrating the same history of national renovation celebrated by 1.2 billion Chinese compatriots was perfectly sensible. ${ }^{24}$ The sponsors conducted a poll during the forum to collate the response of the clergy. Luk Fai, one of the speakers, pointed out explicitly that the proposed service and other related activities would not be held if the polls from the two forums did not show sufficient support from the clergy and lay Christians. ${ }^{25}$

Clergy attending the forum held different views and a consensus of opinion was 
absent. During the two-hour forum, 24 members of the clergy responded to the sponsors' proposal. Gordon Siu, of the Christian Alliance Church and initially one of the sponsors of the proposed service, attracted the attention of the participants when he explained why he had changed his mind:

If we have no choice, then it is perhaps better to do it our own way than to be dictated to. But there are other choices, and one of them is not to do anything. At a time when celebrating the National Day becomes a fashionable activity, our good intentions may be mistaken as a gesture to please the Chinese government. Therefore we should think it over: is this the right time for the church to hold its own celebrations $?^{26}$

Siu is a veteran clergyman widely known among evangelical churches. His change of position had a negative impact on the mobilisation of evangelical clergy. The poll conducted during the forum indicated that although most clergy present believed that it was a good idea to have a 'National Day celebration initiated by the Christian community', they did not think the year 1996 was 'good timing'. ${ }^{27}$ This result later became a strong argument used by opponents of the National Day celebration.

Following the 'Road to Reunification' forum the Christian Times became an arena for debates between the supporters and the opponents of the proposed service, with the latter outnumbering the former. Supporters claimed that the proposed service would serve as an 'alternative National Day celebration' and would help to broaden the scope of the churches' self-determination. One of the supporters wrote:

For the sponsors, organising National Day celebrations from a Chinese position could be an effective way of averting pressure from the Chinese authorities. In this context, the 'argument of expanding space' is justifiable. In this way church leaders can take the lead, instead of being led, in expressing their patriotism. They do not need to celebrate following the approach determined by others, or echo official messages. More importantly, they can represent an 'alternative voice' arising out of a religious conscience when other celebration activities are aimed at pleasing the regime in power. While acknowledging their Chinese national identity, Christians can also express their expectations of the nation courageously. ${ }^{28}$

Opponents, however, doubted whether the expression of any alternative Christian viewpoint was possible given the predominantly official nature of National Day celebrations. $^{29}$

Articles in opposition to the proposed service published during this period focused mainly on four aspects. First of all, opponents questioned whether it was necessary for the churches to hold such a service in 1996. One critic said: 'I could not possibly imagine that the government would force the church to organise any celebrations after 1997. Why exactly in 1996 have celebrations become the necessary or best option?'30 Another said: 'The speeches made by the sponsors [as hosts or as floor speakers] failed to explain in specific terms why the churches must start rehearsing National Day celebrations in 1996. ${ }^{31}$ Critics also questioned the motives and moral courage of the sponsors. One said:

Several sponsors have repeatedly pointed out that the rationale behind the proposal is coming to terms with reality. This strong desire to assure 'survival' and self-protection makes nonbelievers wonder: since when has the church in Hong Kong, whose mission is to proclaim the truth, become 
so easily compromised $?^{32}$

Thirdly, the patriotic virtues of the sponsors were challenged. Certain critics maintained that patriotism could not replace reason. One critic observed: 'They tried in vain to relate National Day celebrations to ideas such as solidarity with Chinese compatriots, reunification and patriotism. Every speech made was full of patriotic feeling and expectations for reunification. But then none of them celebrated the National Day in the past.' ${ }^{33}$ Another wrote:

The sponsors often resorted to patriotic feelings but did not try to discuss the matter in a sober and rational manner. They shared their experience of past humiliation suffered as a result of the absence of national identity, or claimed that they had always had a strong affection for China and Hong Kong. But still they failed to give the Christian community in Hong Kong a sensible answer to the question: Why is it imperative for the Hong Kong churches to express their patriotism by celebrating the National Day ${ }^{34}$

Finally, critics were also doubtful about the effect of such activities. A Christian journalist pointed out that

According to Chinese political standards, the proposal to take the initiative in organising the churches' own National Day celebrations and the suggestion that the nation should not be the exclusive claim of the ruling party are potentially subversive, a fact that the general public will find difficult to understand. The media tend to put things in extremes: either you are pro-democracy or you are pro-China. If you are not prepared for martyrdom then you must be trying to betray Hong Kong. Naturally then, organising National Day celebrations represents a move to please the communist rulers. Now if the media do not understand, so much less would the public. While it is impracticable to ask everybody to understand one's true motives in doing anything, the positive effect of an action which may have profound social implications will be undermined if the action is not correctly interpreted by the public. It may even result in undesirable consequences..$^{35}$

The sponsors answered these queries later in the Christian Times, ${ }^{36}$ but they failed to satisfy their opponents. Subsequent criticisms continued to focus on these four aspects, but the questions asked became increasingly extensive.

\section{Public Response}

A Ming Pao Daily report on the controversy aroused wider media attention. The 'Road to Reunification Forum for Clergy' was widely reported by local newspapers, ${ }^{37}$ and the event became a subject for columnist commentaries. ${ }^{38}$ The commentaries were at first mildly toned, but remained suspicious of the sponsors' intentions. Yu Kam Yin wrote in the Hong Kong Economic Journal:

During the Lutheran World Assembly, Reverend Lo Lung Kwong criticised the Lutheran Church for seeking approval from the Chinese authorities. Now he himself is seeking the support of Christian leaders in order to enhance the profile of the Proposed Service. In fact, he can just go ahead and hold the service without bothering to seek the mandate of the 
Christian community. Why bother? ${ }^{39}$

The sponsors actually wrote a letter to the Hong Kong Economic Journal in response to the query. ${ }^{40} \mathrm{Yu}$ Kam Yin's comment represented, to a great extent, the media's general interpretation and perception of the proposed service.

The sponsors had numerous opportunities to explain their intentions in the media and to build a positive image for the proposed service. Towards the end of May 1996 they briefed the press and distributed the results of the poll conducted during the 'Road to Reunification Forum for Clergy'. When one reporter asked whether the service was contemplated in response to a request by the NCNA, Carver Yu responded:

It is very common for the church in any country to celebrate the National Day. As Chinese, it is only sensible for us to show solidarity with our compatriots and express approval of the reunification. If Hong Kong were reuniting with Taiwan, I would also celebrate the Double Ten [10 October]. ${ }^{41}$

Carver Yu was apparently unaware of the opportunistic overtone in his speech, which invited instant, ruthless criticism from commentators. Fan Chung Lau wrote in the Hong Kong Economic Journal:

Any Chinese in mainland China, Taiwan or Hong Kong, regardless of his or her political position, would agree that 1 October is the National Day for a China under communist rule. It is simply hypocritical to ignore history and put aside our emotions and celebrate a China that exists in abstract conception only, and to insist that celebrating 1 October does not suggest approval of the current regime. If we want to express solidarity with our compatriots, why should we have waited until this day? Does it mean that the church in the past was claiming solidarity with colonialism? These are just lies! To put it simply, the saints of the church are bearing the same cross as any other mortal creatures: they must compromise with certain political rules in order to survive. ${ }^{42}$

Fan's interpretation, which described the church leaders as bowing to the Chinese government, was a setback to the sponsors' mobilisation efforts. The unfriendly criticism from commentators reflected the narrow focus of the sponsors in seeking the support of church members and their failure to win the support of the mass media. It was unfortunate that they earned themselves a negative image because of their lack of experience in communicating with the media. This happened time and again in the latter stages, further undermining the legitimacy of the proposed service.

\section{Internal Opposition}

By June 1996 the controversy over the proposed service was common knowledge in the Protestant community. On 8 June the Ming Pao Daily devoted half a page to a forum discussing the question. Four people contributed to the discussion. Raymond Fung repeated the arguments he had advanced in his earlier Christian Times article. ${ }^{43}$ This was one of the few opportunities available to the sponsors to explain their intentions and rationale to the public through the press, but Fung's effort was overshadowed by the perspectives presented by the other three critics. Arnold Yeung, a veteran theologian, said: 
The United Front tactic of the Chinese Communist Party, aimed at winning over popular support, has always been effectively used. A necessary tool in applying the tactic is the 'handle', and these organising activities, claimed to be undertaken in a personal capacity, may well serve as 'handles'. I am not saying that it is the intention of the sponsors to respond to the United Front effort, but in reality they may just have already done so. ${ }^{44}$

Yeung guessed that the sponsors might have been lobbied by the Chinese authorities into heading this event. Kung Lap Yan, a clergyman and theologian, also criticised the church leaders for lacking 'sound and solid theological grounds', and agreed that 'the proposed service is indeed a strategic arrangement'. He said:

This strategic arrangement gives rise to another question. Is our celebration based on genuine patriotism or is it just a show? If we don't have any affection for our country, celebrating the National Day would be a painful experience. On the other hand, we don't necessarily have to celebrate the National Day even if we do have strong feelings for our country. ${ }^{45}$

Kung's arguments gave rise to the question as to why the Christian Church as a whole should be taking part in a strategic arrangement for which a sound theological basis was absent. Rose $\mathrm{Wu}$, an activist involved with Christian social groups, repudiated the idea of the proposed service without reservation:

Celebrating the National Day is a means used by the Communist Party to beautify its notorious regime. The lesson of the 4 June Incident is that we should support China's democratic movement so that her people may stand up and become real masters of their own fate. That is what a Chinese patriot should do. Participation in National Day celebrations is tantamount to showing approval of the dictatorship of the Communist Party and rejoicing in its rule. It is contrary to all patriotic virtues. Once the churches were involved in such celebrations, they would be likely to be subject to the United Front's tactics and thereby lose their independence. It is an extremely unwise option. ${ }^{46}$

The sponsors thus again failed to paint a positive image in the media through the Ming Pao forum. On the contrary, the credibility of the church leaders was undermined. Lay members of the Protestant Churches started to voice criticism of the sponsors. This was something which had rarely happened in the past: it was not customary for local Christians to criticise their church leaders.

A fatal blow came in mid-June when certain Christian social groups started campaigns in opposition to the proposed service. After the 'Road to Reunification Forum for Clergy' had taken place, seven Christian groups decided to hold a separate meeting before the second 'Road to Reunification' forum so that opponents would have an opportunity to voice their opinions. ${ }^{47}$ An advertisement was placed in the Ming Pao Daily on 12 June calling on lay Christians to participate in a open forum entitled 'Road to Reunification: the Decision of the Church' to be held on 14 June. The meeting was attended by more than 100 people, including reporters from the local and international media. About 40 participants spoke at the meeting, which lasted for more than two hours. Most of the speakers disapproved of the proposed service $^{48}$ Sponsors Raymond Fung and Gideon Yung also attended the meeting to defend their cause. Fung explained that their intention was precisely to avoid holding 
celebrations in the official NCNA style. Yung pointed out that over the past 40 years there had been events in China that had been worth 'celebrating', such as the emergence of personalities like Wei Jingsheng, Wang Xizhe and Wang Dan (well-known proponents of democracy in contemporary China) and events such as the 5 April Incident (when people gathered on Tiananmen Square in 1976 to oppose the rule of the 'Gang of Four') and the 4 June Incident (the Tiananmen Square massacre in 1989), events which he referred to as embodying the 'national quintessence' of China. According to Yung, national celebrations could encapsulate mourning and lament as well as praise. He suggested that criticism directed against the sponsors was based on 'superficial and one-sided sentimental impressions'. ${ }^{49}$ Yung's comments resulted only in further challenges to the sponsors by other Christians in the media. ${ }^{50}$ The most severe blow, however, came from Revd Chu Yiu Ming, a wellknown pro-democracy Protestant clergyman enjoying the same level of reputation as the sponsors. Chu pointed out that the proposed service had divided the Christian community. The silent majority as distinguished from the supporters, he argued, would be accused of not celebrating the National Day, while the opponents, including himself, would be obliged to become 'die-hard' antagonists, or in his words, 'pawns who fought in the front line'. 51 This kind of opposition upset the mobilisation plans of the sponsors, some of whom admitted afterwards that they had expected most opposition to come from the conservative wing of the Christian community, whereas it turned out to be the Christian social activist groups which voiced the strongest objections. ${ }^{52}$ The extensive reporting in the media of Chu's sharp opposition also significantly undermined the legitimacy which the proposed service had gained through the reputation of the supporting church leaders.

The heated exchanges at the open forum attracted further media interest in the controversy. On 18 June 1996 the Ming Pao Daily published a report on the controversy under the headline 'The church holds talks over National Day Celebrations; Carver Yu says proposed service is in response to NCNA's request'. The article was presented in a somewhat tabloid style as if revealing secrets from behind closed doors, and Chu's remarks were quoted as if they were the final word. The report said:

Dr Carver Yu, one of the sponsors of the proposed service and vicepresident of the China Graduate School of Theology, admitted that the NCNA Hong Kong officials had been 'going around looking for groups' to hold National Day celebrations, and under such circumstances church leaders had to 'respond' as appropriate..$^{53}$

The Chinese original of the phrase here translated as 'to respond' is used in the local Christian community in a very general sense. Apparently, the Ming Pao reporter took this comment to mean that the proposal to hold a Christian National Day celebration had been made 'in concurrence with the NCNA's request' and highlighted this in the headline. This unfortunate misunderstanding is attributable both to the indiscretion of the speaker and to the tabloid mentality of the reporter. Carver Yu's response was reported later in the article: 'Carver Yu clarified that there had been no hidden agenda and that the sponsors would not insist on holding celebration activities.' At the same time, further exposures were made:

The sponsors have drafted the National Day Rogation, thanking God for granting the nation peace and well-being. ... A document from the meeting sourced by our staff suggests that the sponsors reached a 
preliminary agreement concerning the form of the proposed service, including the above prayer, as early as mid-February..$^{54}$

The reporter was strongly hinting that there had indeed been a hidden agenda and that the sponsors had reached an agreement concerning the proposed service. Common sense, however, suggests that when the sponsors said there was no 'hidden agenda', what they meant was that there were no hidden intentions. The report ended with Chu's comment that 'the Rogation, which carried more "Li Peng" style than Chinese Premier Li Peng himself, was unacceptably hypocritical'.ss The reporter appeared to have made up his mind on the matter in advance.

The unfavourable report in the Ming Pao Daily prompted Carver Yu to write a letter of clarification. According to Carver Yu, when he said that church leaders must produce a 'response', what he meant was they had to 'react'. He also criticised the reporter for attributing to him key words that he had not uttered at all. ${ }^{56}$ Carver Yu reiterated the arguments he had advanced at the 'Road to Reunification' forum and again expressed his affection for the nation. ${ }^{57}$

Despite Carver Yu's attempts to clarify his position, however, the negative impact of the Ming Pao report had already influenced opinion in the Christian community, as was evident in subsequent articles written on the subject. ${ }^{58} \mathrm{Carver}$ Yu's article continued to draw more criticism. The reporter who wrote the 18 June Ming Pao story came back with a reply to Carver Yu's defence: 'the words "responding to the NCNA" were what Carver Yu actually said; they were not put into his mouth by the reporter. Also, the reporter did not see any difference between "responding" and "reacting" and there was no question of making out-of-context interpretations.' ${ }^{59}$ Accusations between Carver Yu and the reporter complicated the whole issue of the proposed service and added an element of suspense.

Meanwhile, lay church members started to voice criticism of the sponsors for their lack of rational discussion. Carver Yu's patriotic sentiments were criticised in an article written by a group who called themselves 'Grassroot Christians':

Chinese people born and raised in Hong Kong, like Carver Yu, might feel exhilarated over the reunification, which enables them to reaffirm their national identity as Chinese. From a Hong Kong perspective, however, grave concerns are felt behind this 'exhilaration'. Such concerns are fully justified by facts. How can anyone share the generalised, abstract patriotic sentiments expressed by Carver $\mathrm{Yu}$ when they are confronted with facts and realities that trouble them? ? $^{\circ}$

The article questioned the arguments that the sponsors had put forward during the church open forums:

Some leaders said that national celebrations held by the church might be in the form of mourning, lamentation and confession, and that Christians could choose their own way of celebrating. But how would we be able to raise a toasting cup when we were lamenting? We simply cannot understand what kind of 'celebration' it would be. .1

A comment was specifically directed against Gideon Yung's criticism of lay members, although it stopped short of naming him:

Despite queries raised from various perspectives (such as state-church relations, political and social development, personal emotions, etc.), one of the sponsors accused lay members of being 'one-sided' and of having 
misunderstood the sponsors. From the perspective of lay Christians, this does not seem to be the right attitude for rational communication. ${ }^{62}$

In conclusion, the article made a plea to the sponsors:

With 1997 approaching, the Hong Kong church is facing unprecedented challenges. Perhaps it is time for the sponsors to relinquish the role of authoritative leaders for the time being and discuss matters with lay members openly and rationally on an equal basis, working together to identify a genuinely 'appropriate response'. ${ }^{63}$

This article constitutes the most rational criticism of the sponsors so far in the course of the controversy.

\section{The Second Millennium}

A second forum, the 'Road to Reunification Forum for Lay Christians', was held on 30 June 1998 and was attended by over 400 people. The programme was substantially the same as at the forum held for clergy. Leaders of various Protestant churches 'shared' their views with the participants and a poll was conducted. ${ }^{64}$ During the meeting the sponsors announced that the proposed service would be renamed the National Day Service (hereafter referred to as the 'renamed service') rather than the National Day Celebration, a decision made after considering the views of lay members. It was also decided that NCNA officials would not be invited and that the Rogation would be replaced by a responsive prayer of penitence. ${ }^{\text {s }}$ Luk Fai, who had stressed earlier that the proposed service would not be held if the polls from the two forums did not show sufficient support from the clergy and lay Christians, changed his position by suggesting that the samples collected were not sufficient to represent all members of the Hong Kong Christian community. Therefore, the sponsors said, they would base their decision on holding the renamed service in 1996 on written opinions submitted during the meeting. ${ }^{\text {(t) }}$

In the subsequent discussion, which lasted for about an hour, 18 participants spoke and, again, no consensus of opinion was formed. Although some participants pointed out that renaming the service did not solve any problems if the basis for the National Day celebration had not been ascertained, ${ }^{67}$ the response of most participants indicated that the renamed service won substantial approval. In particular, the Christians for Hong Kong Society, one of the seven Christian groups that radically opposed the proposed service, began to change its position. Anthony Chiu, the Society's spokesman, said that they were opposed to any activities celebrating the 1 October National Day, but remained open to a National Day service that did not suggest subservience to any political authority. ${ }^{68}$ The sponsors' compromise through renaming the service had successfully improved the legitimacy of the proposed service and partially dispelled the opposition they had provoked. However, others continued to voice extremely critical opinions. In response to sponsor Philemon Choi, who claimed that it was all up to the decision of lay Christians how and when national celebrations should be held or whether they should be held at all, some critics pointed out that the sponsors had been insisting on holding celebrations despite reservations expressed by a substantial number of lay Christians, undermining the lay communities' right to a veto. ${ }^{69}$ Others expressed disappointment over the sponsors' use of the forum simply as an opportunity to clarify their position..$^{70}$ The poll conducted during the forum showed that lay Christians shared the view of 
the clergy. Most of them supported 'National Day celebrations initiated by Christians', but doubted whether the year 1996 was the 'right timing'." The sponsors ignored this pledge to follow the opinion of the clergy and lay Christians. They thus indicated that they were prepared to violate the spirit of the rules of procedure and disregard the results of rational discussion in order to achieve their ends. In so doing, they deprived the proposed event of its legitimate basis by ignoring all democratic procedures.

Debates continued in the Christian Times after the 'Road to Reunification Forum for Lay Christian'. It seemed that many lay Christians had accepted the views of the sponsors and supported the renamed service. A Christian wrote to the Ming Pao Daily and expressed approval of the sponsors' views on the subject of national identity: 'At the 30 June meeting I truly felt the alienation of the Hong Kong people from their country. ... We came to understand that the sponsors were concerned with helping lay Christians to deal with the issue of national identity." 72 Another writer expressed approval of the 'priesthood theology': 'In my opinion, the overtone of the renamed service (offering praise, confession, thanksgiving and intercession to God in a priestly capacity on behalf of the country) is in line with biblical principles. ${ }^{73}$ The general response of lay Christians shows that the second open forum was quite successful, especially in terms of the renaming of the proposed event, the appeal to patriotism and the claim that the service would have a sound theological basis.

Nonetheless, substantial queries were still being raised in the religious community. Some Christians sought to investigate the possibility of identifying even more appropriate names for the celebration, ${ }^{74}$ while others challenged the theology of the sponsors and cast doubt on the idea of national identity:

Clergy and pastors have been citing the priests and prophets of the Old Testament for their patriotism and recalling how the priests offered atonement for sins on behalf of the nation. But the context of Israel in the Old Testament was different from ours in two ways. Israel in the Old Testament practised theocracy, whereby political authority and religious authority were but two sides of the same coin. The love for God and the love for one's nation were inseparable. Secondly, the priestly office is valid only in a country that worships God. It would be irrelevant in an atheistic nation. ... Tibet was conquered and annexed by China several hundred years ago. If Hong Kong Christians should learn from the patriotism of the people of Israel, then Tibetan Christians should also demand the independence of Tibet. They should call for the building of their own country, as did the prophets of Israel. ${ }^{75}$

Other critics provided further comments on the possible undesirable outcome of the National Day celebration:

Electing to express alternative views on 1 October, a highly symbolic date, is time-sensitive. But precisely because of the date's symbolic nature, largely in association with the Chinese communist regime, the deliberate choice of this date for celebration would require a clear political position, otherwise any celebration would be perceived as singing the praises of the current regime. Celebrations held without a stated objective might be interpreted as an act glorifying the ruling regime. ${ }^{76}$

These comments and suggestions from lay Christians were indeed valid criticisms.

In contrast to the sober and rational attitude of the lay members, the sponsors 
became increasingly irrational towards the latter stages of the debate. In response to a speaker who said that he acknowledged his Chinese identity but not the People's

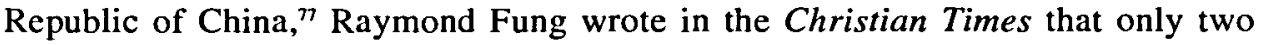
options were available to such people: they should either emigrate or start a revolution, or at least civil disobedience. He said:

This is where the problem lies. He intends to face the future regime after 1997 with the same attitude he does now: cynical, detached, self-pitying and refusing to commit himself. For these people, passports and civil rights confer rights but not obligations. What a triumph for colonialist education to have a person saying 'I am Chinese but I do not acknowledge the People's Republic of China'! The fact that this seemingly courageous statement is uttered by a Hong Kong citizen who will be staying in Hong Kong after 1997 reflects how 'ugly' the Hong Kong people are. ${ }^{78}$

Fung's criticism does not stand up to rational analysis. To refrain from acknowledging a regime because one disapproves of it and to distance oneself from all things related to the regime is surely one way for ordinary citizens to express not just their feelings but also their political position.

Subsequently, a number of theologians also joined the debate. The focus was gradually shifting to the timing of the renamed service. ${ }^{79}$ Lo Ping Cheung commented on the logic of the 'priesthood theology' and questioned the holding of the renamed service on 1 October:

The idea of redeeming a National Day which belongs to the people but has long become captive of the ruling party is in itself questionable. ... We could say that the history of 1 October belonged to the people only if it were the people's power which overthrew the nationalist government and by which the communists were given mandate to rule. But ever since 1949, 1 October has always belonged to the Communist Party but never to the people, so there could be no redemption. ... 1 October is the memorial day for the Communist Party as much as it is for the nation. 1 October is not the birthday of the Communist Party (that should be on 1 July). It is the day on which the communists seized power. To celebrate 1 October is to celebrate communist rule. The celebration of 1 October should therefore be based on the performance of the communist government. If we toast 1 October without regard for the government's deeds, we can hardly be free from suspicion of 'shoe-shining' the government. If we are to celebrate for the nation, we must choose another date. ${ }^{80}$

Kang Phee Seng, another local theologian, also had queries:

If the church is going to celebrate 1 October, why not also celebrate the Double Ten in memory of the 1911 Revolution? Is the Double Ten not a national day? Does it not belong to the people too? Why don't we redeem the Double Ten as well? If 1 October can be viewed as a politically neutral date, much more so is the Double Ten! And for that matter is not 1 July an even more appropriate date for celebrating Hong Kong's reunification with China, and less controversial too? ... The people of Hong Kong have been working diligently on this piece of land and they will continue to do so after 1997. Their solidarity with Hong Kong and China has been expressed through concrete actions. What they don't understand is: Why 
on earth should they be criticised for not facing the reality of reunification just because they don't celebrate on 1 October or raise the Five-Star Flag or sing the national anthem of the People's Republic of China? ${ }^{81}$

Fung criticised Kang as follows:

This is just another version of the 'horse races and night clubs as usual' mentality, more sophisticated in taste but nothing different in essence. Considering the unprecedented historical moment that we are about to face, this BAU [business as usual] mentality is quite astonishing. The problem is not that BAU will harm us in any way (no, BAU is the best way of self-protection); the problem is that we are letting go an opportunity to witness to our faith that comes by only once in a thousand years. To put it in more theological language, we are ignoring God's calling to the Hong Kong churches in this specific historic context. ${ }^{82}$

The meaning of Hong Kong's reunification with China is surely a matter of interpretation. Different interpretations imply different values, attitudes and actions, and this is perfectly understandable. Kang's proposed response to the reunification of Hong Kong with the mainland involved keeping a distance from national symbols and keeping a low profile on the political realities stemming from the reunification. There are two problems with Fung's response to Kang. First, the position of keeping a distance from national symbols is not equal to the position of supporting the status quo (the meaning of 'horse race and nightclubs as usual'). Secondly, Fung needs to argue why his interpretation of the unification as 'an opportunity to witness Christian faith that only comes by once in a thousand years' is better than Kang's interpretation. His statement not only lacks a rational basis, but also conveys an impression of religious fanaticism. It is very unfortunate that a controversy started with the sponsors' advancing their arguments and responding actively to criticisms should have ended with their verbal abuse of opponents of the mobilisation process. That it did so is, at least in part, the reason for the sponsors' failure to initiate a collective politico-religious action.

\section{Public Discussions on the Social Implications of the Controversy}

Meanwhile, the media continued to report on the controversy surrounding the National Day celebrations. Commentators began to show a better understanding of the sponsors' intentions and started to reflect on the social implications of the proposed service in greater depth. The sponsors themselves were also aware of the public interest that the controversy was arousing. Raymond Fung wrote:

Only Christians would bother to spend so much time and effort in debating with their fellow churchmen. This kind of debate would never happen in other communities, where people wouldn't bother to try to convince others. Outside the Christian community no one would bother to listen to the views of others with such attention and pursue matters at such depth. Christians have indeed put on a show before the rest of the Hong Kong community, but this is a highly 'symphonic' show. It helps to clarify an important message for the church and the rest of the community: that the people of Hong Kong will not distinguish between good and evil by 'patriotic' standards. ${ }^{83}$ 
The reality of the controversy does not suggest that such an effect was achieved. Nevertheless, Fung's comments indicate that the sponsors had started to interpret the controversy in the social context of Hong Kong.

Media commentators also produced some inspiring discussions in the latter stages of the debate. $\mathrm{Ng}$ Kwai Heng of the Hong Kong Economic Journal commented accurately: 'The controversy is definitely something more than the internal dispute of a religious group. It shows how certain sizeable and influential civil groups are preparing for the handover and the problems arising therefrom. ${ }^{\prime 84}$ Lau Siu Lun of the Sing Tao Daily observed:

Let's not make the mistake of thinking that the proposed event will end with a moderate conclusion. If any alternative national celebration, say the National Day service, were to be held on any date other than 1 October, it would be tantamount to proclaiming that the most important day for the Chinese nation is not 1 October. This is potentially more 'rebellious' than shouting slogans like 'Down with the Chinese Government' ${ }^{85}$

$\mathrm{Ng}$ and Lau both pointed out the subtle social implications of the controversy. 'While leaders of the Hong Kong Alliance in Support of the Patriotic Democratic Movement in China ${ }^{86}$ await 1997 with a martyrdom mentality,' asked $\mathrm{Ng}$, 'will the "alternative national celebrations" proposed by the church offer a new choice for civil groups who wish to do something?' ${ }^{87}$ Lau argued as follows:

Popular views hold that in respect of National Day celebrations there can be only two positions: either you are inside joining the party or you are outside protesting. Either you acknowledge the present Chinese government and propose a toast, or you insist that it is an unjust government that should be fought against. Until now these have been the only options we have made available to ourselves. Understood in this context, the controversy is significant because it represents the final reflections on the issue of 'How the Hong Kong people should face China'.... The controversy may end without any concrete action being taken, but in undertaking this exercise of rethinking, Christians are in fact acting on behalf of the entire Hong Kong community and, as such, they have indeed done a good job. ${ }^{88}$

The perspectives of the two commentators suggest dimensions that the sponsors had yet to consider. The key was whether the religious community could undertake rational criticism of the state-society relationship and whether the reflections and conclusions of the religious community could become an example to inspire other social groups. It is regrettable that the sponsors failed to adopt a broader social vision. As a result, the scope of the debate was limited to the religious community and no positive and profound impact was made on society.

\section{Conclusion}

In this paper I have sought to analyse the emergence and development of the controversy, and to investigate the factors underlying the failure of the sponsors to mobilise the religious community to participate in a politico-religious collective action against the Chinese government's call to uphold nationalism. There were a number of important internal factors: the idea of the proposed service and its theological basis were questioned by clergy and theologians; the backing-down of some 
sponsors and explicit opposition on the part of well-known church leaders undermined the legitimacy of the proposed service; and finally, the counter-movement launched by Christian social groups weakened the sponsors' mobilisation efforts. Outside the Christian community, the proposed service failed to build a positive image or gain the support of the mass media because of the scepticism and criticism of reporters; distorted messages were conveyed to the public by reporters as a result of miscommunication between the sponsors and the media; and mobilisation efforts were further weakened in the Christian community as a result of the negative images and distorted messages carried by the mass media.

The sponsors were not consistently in a disadvantaged situation. They had many opportunities and channels to explain their ideas and clarify misunderstandings. They might have engaged in rational-critical discourse with their opponents, accepted polemical ideas on the basis of better argument and thereby enhanced the legitimacy of the proposed service. In fact, it is quite extraordinary that a politico-religious action against the Chinese government's call to uphold nationalism should at the very outset secure the support of 47 church leaders. The two polls showed that the proposal of a National Day celebration initiated by Christians was widely supported, although most participants disagreed over the timing of the event. The sponsors' compromise in renaming the proposed service was also widely supported. Nevertheless, because of their own limitations they failed to overcome obstacles that emerged in the process of debate. The sponsors tended to rely on their own reputations as church leaders to mobilise members of the Christian community. They appealed too much to the national sentiments of the Chinese people but did not show proper regard for rational-critical discourse. They conducted polls but did not act according to the results. They showed disregard for the spirit and implicit rationale of the rules of procedure, depriving themselves of probable support from clergy and lay Christian. Certain sponsors were not very experienced in dealing with the media, which resulted in the dissemination of distorted messages and misrepresentations. The dispute over the meaning of certain words ('to respond' or 'to react') was not resolved and the alleged 'hidden agenda' was not effectively clarified. Moreover, disagreement over the timing of the proposed event added fuel to the fire. The sponsors became rather irrational towards the latter stages of the controversy and began attacking their opponents. They were concerned only with the implications of the proposed service for the religious community and failed to comprehend its potential broader impact.

The controversy provides a text for discussion and reflection in relation to Calhoun's theory of civil society. To a great extent, the controversy as a test case proves to be consistent with the theory in terms of constituting factors, including political groups facing state domination and the integration of communities on the basis of rational-critical discourse. Because of the limitations of the sponsors and the fact that the scope of the debate did not extend beyond the Protestant community the controversy does not provide sufficient evidence to support the third criterion of Calhoun's theory, namely the development of democratic inclusiveness within a whole political community through the process of rational-critical discourse. Nevertheless, given the variety of members of the Protestant community (church leaders, theologians, clergy, Christian social groups and lay Christians) who were involved, and given the social implications observed by non-Christian commentators, the transition from rational-critical discourse to democratic inclusiveness within this particular community is shown to be not only possible but also desirable. The controversy justifies the relevance of the civil society theory in Asia and opens up a new 
frontier for China studies: can religious communities help to promote the development of a civil society in the Chinese context? ${ }^{89}$

Although this paper concludes with an optimistic interpretation of the implications of the controversy, I am aware that certain Protestant cultural characteristics, which may not be present in other social groups, were instrumental in maintaining the community's solidarity even when its members were engaged in intense debate among themselves. For example, both the sponsors and their opponents stressed unity during the course of the debate. ${ }^{90}$ For members of the Protestant community, the unity of believers and the avoidance of segregation was a matter of religious obligation. Through this power of social integration stemming from religious faith, members maintained their communal identity even while fiercely debating with each other. In other words, the Christian faith has already provided for the Protestant community the cultural capacity of 'communality' and 'integration' which Calhoun suggests is supposed to be obtained from rational-critical discourse. ${ }^{91}$ By that token, it remains to be seen whether it is possible for other social groups that do not purport to bear the above Protestant characteristics to integrate into a political community through rational-critical discourse. ${ }^{92}$

\section{Notes and References}

1 Pro-China groups such as Xianggang Gonghui Lianhehui (the Hong Kong Federation of Trade Unions) and Xianggang Minzhu Jiangang Lianmeng (the Democratic Alliance for the Betterment of Hong Kong) held celebrations. Other groups included Gangdao Gejie Qingzhu Huigui Huodong Chouweihui (the Hong Kong Island Reunification Celebration Committee) and Funu Qingzhu Jiuqi Huigui Chouweihui (the Reunification Celebration Committee of Women). On the other hand, Minzhu Dang (the Democratic Party), Fandui Linshi Lifahui Dalianmeng (the Alliance Against the Provisional Legislative Council) and Qiyi Lianxi (the July 1 Link) organised 'anticelebration' activities. The July 1 Link is an alliance of several Protestant groups. See Choi Yeung Mei, “"Wanquan qingzhu” huo "fan qingzhu" xian rechao: huigui daoshu huodong tuanti zhengxiang "biaobai" ('Society heated up with "total celebrations" or "anticelebrations": groups engaged in reunification celebrations and countdowns to "declare position"'), Ming Pao Daily, 26 June 1996.

2 The Ming Pao Daily devoted half a page to publishing articles by the sponsors and their opponents on 8 June and 9 July 1996 respectively. Other international reports include: Lynette Clemetson, 'A test of faith and hope: Christians try to adjust to a future under communist masters', Newsweek, 10 June 1996, pp. 16-17; Jesse Wong, 'Crisis of faith: the China question splits Christians in Hong Kong', Asian Wall Street Journal, 17 July 1996, p. 1; Melana K. Zyla, 'Devil of a dilemma: churches ponder how close to get to Beijing', Far East Economic Review, 1 August 1996, p. 17; Todd Crowell, 'Christians wrestle over ties with atheist China', Christian Science Monitor, 7 August 1996, p. 1.

3 Hank Johnston and Jozef Figa, 'The church and political opposition: comparative perspectives on mobilization against regimes', Journal for the Scientific Study of Religion, vol. 28, no. 4, 1989, pp. 493-508; David Lehmann, Democracy and Development in Latin America: Economics, Politics and Religion in the Post-war Period (Polity Press, Cambridge, 1990); Daniel H. Levine, 'From church and state to religion and politics and back again', in Howard J. Wiarda (ed.), Politics and Social Change in Latin America (Westview Press, Boulder, CO, 1992), pp. 170-94; James R. Wood and Jon P. Bloch, 'The role of church assemblies in building a civil society: the case of the United Methodist general conference's debate on homosexuality', Sociology of Religion, vol. 56, no. 2, 1995, pp. 121-36; Robert Wuthnow, Christianity and Civil Society: the Contemporary Debate (Trinity Press International, Valley Forge, PA, 1996).

4 Mary B. Rankin, 'The origins of a Chinese public sphere', Études Chinoises, vol. 9, Autumn 1990, pp. 1-60; William T. Rowe, 'The public sphere in modern China', Modern 
China, vol. 16, July 1990, pp. 309-29; David Strand, 'Protest in Beijing: civil society and public sphere in China', Problems of Communication, vol. 29, May-June 1990, pp. 1-9; Jeffrey N. Wasserstrom and Elizabeth Perry (eds), Popular Protest and Political Culture in Modern China: Learning from 1989 (Westview, Boulder, CO, 1992).

5 Craig Calhoun, 'Civil society and the public sphere', Public Culture, vol. 5, 1993, pp. 267-80.

- There were a variety of interpretarions of the proposed service. Some believed that the idea had not come from the sponsors themselves, but that the sponsors had been invited to back the idea by the New China News Agency (NCNA). See Chu Yiu Ming, 'Zichou shiyi guoqing beihou dongji zhaoran ruojie' ('The real motive behind the proposed National Day celebrations is more than evident'), Si, nos. 45-46, October 1996, p. 11. Some believed that church leaders had been subject to the 'united front' efforts of the NCNA and that the whole incident was 'basically a process of power struggle and transfer within Protestantism'. See Mau Chi Wang, 'Jiaohui zichou guoqing di huangmiu' ('The absurdity of the proposed Christian National Day celebrations'), ibid., p. 21. Others believed that the proposed service had been aimed at exchanging sovereignty for the right of independent action. Through the proposed service the church would be acknowledging the sovereignty of the People's Republic of China and the communist regime and in return it would be allowed to celebrate in its own way. See Ng Kwai Heng, 'Cong zhengzhi cengmian kan jiaohui renshi ban gaoqing' ('The church's involvement in National Day celebrations from a political perspective'), ibid., p. 23.

7 The NCNA would invite various groups to hold celebrations every year on 1 October, the National Day of the People's Republic of China. Since 1995 a National Celebration Committee of Religious Groups (Zongjiaojie renshi guoqing chouweihui) has been in existence, involving the six major religions in Hong Kong (Protestants, Catholics, Buddhists, Taoists, Confucians and Muslims). Some church members have been disturbed by the NCNA's gesture in June 1995 inviting Christian leaders to take up roles in organising National Day celebrations among religious groups. Raymond Fung, one of the sponsors, explained the rationale of the proposed service as follows: 'If we do not hold it this year ... it is very possible that the official approach will dominate future celebrations and the churches and Christians will lose the initiative because they fail to reach an agreement among themselves. ... It is very likely that the schools will be celebrating the National Day next year and there will not be any exception for Christian schools. I do not know who will give the instructions, but in the absence of any other acceptable alternative approaches, the schools will be obliged to follow the official approach. If we contemplate our own approach in 1996, there will be a chance for the staff and students of church schools to participate.' See Raymond Fung, 'Weishenmo zai jiulin' ('Why in 1996'), Christian Times, no. 460, 23 June 1996, p. 10.

8 Carver $\mathrm{Yu}$, another sponsor, said: 'While agreeing that the church should celebrate the National Day, [clergy] believe that celebrations held by civic groups should not be manipulated by the Party or the government, in such a way that they become occasions for singing the praises of the ruling regime. ... The clergy's "reaction" is to propose alternative National Day celebrations. We are going to raise our cups to God, not Chinese officials. We will offer confession, thanksgiving, intercession and commitment in a priestly capacity.' Carver Yu, 'Jiaomu chouban guoqing de benyi yu wuhui' ('The original intentions of proposing the National Day celebration and subsequent misunderstandings'), Ming Pao Daily, 27 June 1996.

9 The sponsors openly debated with their opponents on a number of occasions, such as the 'Road to Reunification Forum for Clergy' held on 24 May 1996 and the 'Road to Reunification Forum for Lay Christians' held on 30 June 1996, with the attendance of over 250 and 400 participants respectively. The forum 'Road to Reunification: the Decision of the Church' organised by the opponents was attended by over 100 participants. The third meeting in a series of seminars under the general theme of 'Reflections on the StateChurch Relationship in the Current Context', organised by the Fellowship of Evangelical 
Students and entitled 'The Principles and Practice for Church Involvement in Politics Before and After 1997', held on 4 July 1996, was attended by more than 700 participants.

Cheung Yuk Wan et al., 'Gaodiao yunniang, didiao jinxing: shouci "shiyi" gaojiari chongbai yu yibaiershu ren canjia' ('Low-profile launch against high-profile preparations: the 1 October National Day service attended by over 120 people'), Christian Times, no. 475, 6 October 1996, p. 1.

" 'Gaojiari chongbai jin sanshi ren canjia' ('National Day service attended by about 30 people'), Christian Times, no. 528, 12 October 1997, p. 2.

12 According to Carver Yu the idea of a National Day Celebration Service was proposed by Raymond Fung, who called on Gideon Yung, Lo Lung Kwong and Kwok Nai Wang to discuss the matter. The first meeting was held on 20 November 1995. See Carver Yu, 'Jiaomu chouban. ...'

13 See the text of the invitation letter. The letter was undersigned by $\mathrm{Ng} \mathrm{San} \mathrm{Ho,} \mathrm{Yu} \mathrm{Miu}$ Wan, Li Ping Kwong, Wilson Chow, Gideon Yung, Kwok Nai Wang, Lincoln Leung, Tso Man King, Raymond Fung, Samuel Chu, Philemon Choi, Lo Lung Kwong, Lo Cho Ching and Gordon Siu.

14 Li Wai Ling, 'Fagi guoqing huigui lianchuan huodong: Lu Longguang buyuen zuo tuoniao' ('Lo calls for National Day and reunification celebrations and refuses to be evasionist'), Ming Pao Daily, 8 May 1996, p. 1.

is Zunzi, a local cartoonist famous for his political caricatures, expressed his disapproval of the proposed service on the same day that the news was reported with a cartoon depicting a crucified Christ dressed in a Dr Sun Yat-sen suit, with the Chinese characters 'Qingzhu guoqing' ('Celebrating the National Day') written on top of the cross. Two Christians, standing beneath the cross with hands in a praying posture, look perplexed. Ming Pao Daily, 8 May 1996, p. 2.

16 See the text of the invitation letter. The following clergy joined as signatories: Lee Ching Chee, Lam Sung Che, Wu Ping Kit, Woo Ming Tim, Yuen Tin Yau, Fung Shiu Wing, Luk Fai and Siu Hoi Lei.

17 Raymond Fung, 'Chang "tianyou nuwang” lai aiquo?' ('Expressing patriotism by singing "God save our Queen"'), Christian Times, no. 449, 7 April 1996, p. 10.

18 Raymond Fung, 'Jisi xiang shen jubei' ('Raising the cup of thanksgiving to God as his priest'), Christian Times, no. 455, 19 May 1996, p. 10.

19 Raymond Fung, 'Xiang shen jin le yi hou' ('After fulfilling our duties to God'), Christian Times, no. 456, 26 May 1996, p. 10.

ibid.

2 ibid.

2 Church leaders who expressed their views in the forum include Luk Fai (Church of Christ in China), Lo Lung Kwong, Li Ping Kwong (both United Methodist), Carver Yu (China Graduate School of Theology), Lo Cho Ching (Tsung Tsin Mission) and Lee Kam Hung (Christian Times). Philemon Choi (Breakthrough Limited) was absent. See $\mathrm{Ng} \mathrm{Lai} \mathrm{Ha,}$ 'Zixing chouban guoqing, jiaomu yijian fenyurn' ('Clergy divided over Christian National Day celebrations'), Christian Times, no. 457, 2 June 1996, pp. 1-2. ibid., p. 1 .

ibid., p. 2.

ibid., p. 1.

ibid., p. 1 .

The poll was conducted with a questionnaire seeking opinion on three statements: (1) National Day celebrations initiated by Christians are worth supporting; (2) the year 1996 is a good time for the event; (3) The forum has enhanced my support for the event. Most answers to the first question were affirmative, whilst most answers to the second and third questions showed disapproval. ibid., p. 2. 


\begin{tabular}{ccccccc}
\hline Statement & $\begin{array}{c}\text { Strongly } \\
\text { disagree }\end{array}$ & Disagree & $\begin{array}{c}\text { No comment/ } \\
\text { not applicable }\end{array}$ & Agree & $\begin{array}{c}\text { Strongly } \\
\text { agree }\end{array}$ & $\begin{array}{c}\text { Not } \\
\text { answered }\end{array}$ \\
\hline Q.1 & 29 & 30 & 21 & 36 & 34 & 2 \\
Q.2 & 41 & 35 & 29 & 20 & 26 & 1 \\
Q.3 & 24 & 33 & 36 & 29 & 22 & 8 \\
\hline
\end{tabular}

28 Ying Fuk Tsang, 'Gaoqing geiwo de tiaozhan' ('My National Day challenge'), Christian Times, no. 461, 30 June 1996, p. 8.

${ }^{29}$ See Wu Chi Wai, 'Huigui lushang jingji mantu' ('A thorny road to reunification'), Christian Times, no. 462, 7 July 1996, p. 8; Yuen Mi, 'Guojiari fenbo' ('The National Day controversy'), Christian Times, no. 461, 30 June 1996, p. 2; Chan Ka Wai, 'Jiaohui haoxin zuo huaishi?' ('Evil results from good intentions of the church?'), Christian Times, no. 474, 29 September 1996, p. 9; Ho Man Cheung, “"Huigui lushang" jiaomu tonggong yantaohui huogan' ('Reflections on the "Road to Reunification Forum for Clergy"'), Christian Times, no. 458, 9 June 1996, p. 8.

30 Ho Man Cheung, op. cit.

31 Wu Chi Wai, op. cit.

32 ibid.

33 Ho Man Cheung, op. cit. See also Tong Xiaojun, 'Shiwen aiquo jingshi qianzhongjie' ('The patriotism complex'), Christian Times, no. 458, 9 June 1996, p. 9.

34 Wu Chi Wai, op. cit.

$3 s$ Yuen Mi, op. cit.

36 Luk Fai, 'Huigui lushang de qige kunhuo yu jueze' ('Seven dilemmas and options on the road to reunification'), Christian Times, no. 460, 23 June 1996, p. 8.

${ }^{37}$ See 'Jidujiao dui yingfou choubei guoqing yijian fengi' ('Christians divided over National Day celebrations'), Hong Kong Economic Journal, 24 May 1996; 'Jiaohui niban shiyi guqing huodong' ('The church has plans for celebrating the National Day on 1 October'), Ming Pao Daily, 25 May 1996.

${ }^{38}$ Cf. Yu Ming, 'Jiaohui yingfou qingzhu guoqing qi zhengyi' ('Dispute on National Day celebrations for the church'), Ming Pao Daily, 28 May 1996; Mau Chi Wang, 'Moxing zhishou zheng ganyu xianggang jiaohui' ('The invisible hand is over the Hong Kong church'), Sing Tao Daily, 30 May 1996; Yu Ming, 'Jidujiao guoqing huodong jidiao' ('The basic theme of Christian national celebrations'), Ming Pao Daily, 10 June 1996.

39 Yu Kam Yin, 'Jiaohui qingzhu guoqing fengbo yunao yuda' ('The Christian National Day celebration controversy becomes increasingly contentious'), Hong Kong Economic Journal, 29 May 1996.

40 Lo Lung Kwong, 'Chengqing "xianggang maibo" de piping' ('Clarifications in response to the comments of "Pulse of Hong Kong"'), Hong Kong Economic Journal, 1 June 1996.

41 See 'Banshu jidutu fandui jinnian ban guoqing juhui' ('Half the Christian community against holding National Day celebrations this year'), Ming Pao Daily, 1 June 1996.

42 Fan Chung Lau, 'Jidu jiaohui congrong ban guoqing' ('The church to hold National Day celebrations in concurrence with popular trends'), Hong Kong Economic Journal, 7 June 1996.

43 Raymond Fung, 'Daibiao zhongguo xiang shangzhu jubei' ('Raising the cup of thanksgiving to God on behalf of China'), Ming Pao Daily, 8 June 1996.

44 Arnold Yeung, 'Bei tonzhan de weiji' ('The danger of being subject to the united front tactic'), Ming Pao Daily, 8 June 1996.

45 Kung Lap Yan, 'Jidutu chouban guoqing nai celuexing zhenyi' ('Christian National Day celebrations as a strategic arrangement'), Ming Pao Daily, 8 June 1996. In another article he explained the reasons why he considered National Day celebrations as lacking 'a sound and solid theological basis'. He believed that the priest could redeem only what originally belonged to God, like the people and the government. The notion of 'redeeming the National Day' was an attempt to turn a political question into a religious one. See Kung 
Lap Yan, 'Cong Mading Lude de liangge guodu kan jinqi guoqing zhenlun' ('The two kingdoms of Martin Luther and the recent National Day celebration controversy'), Si, nos. 45-46, October 1996, pp. 38-42.

th Rose Wu, 'Chouban guoqing dengru aiquo?' ('Is celebrating the National Day the same as being patriotic?'), Ming Pao Daily, 8 June 1996.

${ }^{47}$ Christian social groups are Christian groups which are independent of the established churches and which engage in social or political affairs. The seven groups are the Hong Kong Christian Institute, the Hong Kong Student Christian Movement, the Christians for Hong Kong Society, the Hong Kong Women's Christian Council, the Catholic Youth Council, the Hong Kong Christian Industrial Committee and the Justice and Peace Commission of Hong Kong Catholic Diocese.

48 The seven groups also organised polls in their forums. These asked for responses to four statements: (1) It is appropriate, in principle, for an individual Chinese to initiate Christian National Day celebrations; (2) It is appropriate, in principle, for a group of Christians to initiate Christian National Day celebrations; (3) It is appropriate, in principle, for a group of Christians to initiate Christian celebrations of the National Day on behalf of other Christians; (4) Initiating Christian celebrations of the National Day is appropriate in the current political situation. The results of the 97 questionnaires collected were as follows:

\begin{tabular}{ccccc}
\hline Statement & Disagree & No comment & Agree & Not answered \\
\hline Q.1 & 39 & 37 & 18 & 3 \\
Q.2 & 29 & 44 & 19 & 5 \\
Q.3 & 3 & 83 & 7 & 4 \\
Q.4 & 12 & 75 & 10 & 0 \\
\hline
\end{tabular}

Only five people believed that the year 1996 was the right time to hold the celebrations. Only one believed that 1 October 1996 was the right timing. As to the date for holding National Day celebrations in 1997, 1 October, 4 June, Double Ten and Christmas Day (25 December) were all among participants' choices. See 'Qianxian qunti ban xintu zixun dahui, diaocha zhi jiaohui buyi zichou guoqing' ('Front-line groups hold open consultation; poll results against church involvement in National Day celebrations'), Christian Times, no. 461, 30 June 1996, p. 10; and 'Jidutu duo fandu ban guoqing juhui' ('Majority of Christians against National Day celebrations'), Ming Pao Daily, 29 June 1996.

49 See "Huigui lushang jiaohui de jueze" luntan: xintu duo fandu ban "shiyi" guoqing' ("Christian National Day celebrations on 1 October opposed by most participants in the decision of the church forum'), Ming Pao Daily, 15 June 1996. See also 'Jidutu fandu zixing chouban guoqing, faqiren biaoshi keyi gao linglei qing zhu' ('Christians oppose National Day celebrations by the church; sponsors suggest alternative celebrations'), Hong Kong Economic Journal, 15 June 1996.

so See Yiqian jiceng de jiduijiao jiaoyou (Grassroot Christians), 'Jiaohui lingxiu fali miandui piping' ('Church leaders' deficiency in answering criticisms'), Ming Pao Daily, 2 July 1996.

st See note 49.

52 Lo Lung Kwong said he was surprised to find that most opposition came from the frontline Christian groups that he had been so familiar with. See 'Jidujiao juan chouzhu guoqing qude liangjie' ('The Christian community reaches understanding concerning National Day celebrations'), Hong Kong Economic Journal, 1 July 1996.

53 'Jiaohui taolun ban guoqing huodong: Yu Daxin shuo nai "huiying" Xinhuashe' ('The church holds talks over National Day celebrations; Carver Yu says proposed service is in response to NCNA's request'), Ming Pao Daily, 18 June 1996.

$\$ 4$ ibid.

$5 s$ ibid.

so Carver Yu, 'Jiaomu chouban. ...'

57 Carver Yu, 'Buyuen zaizyi moquo zhimin' ('Should we remain a people without a national 
identity forever?'), Ming Pao Daily, 28 June 1996.

A lay Christian wrote: 'These leaders tried to evade the question at first, but at last they were obliged to admit that "the NCNA Hong Kong officials had been going around looking for groups" to hold National Day celebrations, and under such circumstances church leaders had to "respond" as appropriate.' See Jingbing (Soldier), 'Qingzhi guoqing de beihou' ('Behind the proposed celebrations'), Ming Pao Daily, 9 July 1996. Chan Yi Fung reported the incident in The Nineties: 'An "understanding" has long been reached among themselves concerning " 1 October" celebrations. They have even drafted the prayer.' See Chan Yi Fung, 'Weidao jinqi jidujiao yi fenlie?' ('Is the Christian Church facing a split even before 1997?'), The Nineties, August 1996, p. 46. Chu Yiu Ming wrote: 'Clergy had been doubtful about the sponsors' claim that there had been no hidden agenda. A meeting agenda dated 12 February was then disclosed, listing celebration programmes and details such as hanging the National Flag in the venue and inviting NCNA officials as "guests", etc. The event was entitled "Reception and Service of Christian Celebration of National Day of the People's Republic of China".' See Chu Yiu Ming, 'Zichou shiyi. ...' Mau Chi Wang wrote: 'The 18 June report of Ming Pao Daily discloses the prayer, reception and service form planned by the sponsors. So how can they say there has been no hidden agenda? Moreover, they did not admit that the proposal was made in response to a request from the NCNA until the 18 June report. Until then, they faltered and denied there was any intervention by outside forces. All of a sudden, the truth is revealed.' See Mau Chi Wang, 'Jiaohui zichou. ...'

s9 A Ming Pao reporter, 'Huiying Yu Daxin "chengqing"' ('Reply to Carver Yu's clarification'), Ming Pao Daily, 9 July 1996.

60 Yiqian jiceng de jidujiao jiaoyou (Grassroots Christians), 'Aiguo de beihou' ('Behind patriotism'), Ming Pao Daily, 1 July 1996. For other criticisms, see Yiwei pingfan de jinxinhui xintu (An ordinary Baptist Christian), 'Bu rentong Yu mushi de linian' ('Disagreement with Revd Yu's idea'), Ming Pao Daily, 9 July 1996.

61 Yiqian jiceng de jidujiao jiaoyou, 'Aiguo de beihou'.

62 Yiqian jiceng de jidujiao jiaoyou, 'Jiaohui lingxiu fali miandui piping'.

63 ibid.

64 Church leaders who expressed their views in the forum include Luk Fai (Church of Christ in China), Philemon Choi (Breakthrough Limited), Carver Yu (China Graduate School of Theology), Lo Lung Kwong (Methodist Church) and Gideon Yung (Fellowship of Evangelical Students). See Cheung Yuk Wan et al., 'Jiaohui guoqing huodong yiming guojiari, sishiqi ming faqiren buri jueding shifou juxing' ('Christian National Day celebrations renamed National Day service; 47 sponsors will shortly decide whether to proceed'), Christian Times, no. 462, 7 July 1996, p. 1.

os 'Jidujiao juan ...'.

of Cheung Yuk Wan et al., 'Jiaohui guoqing ...'.

(7) ibid.

${ }_{68}^{68}$ See 'Jidujiao juan ...'?

69 ibid.

70 See 'Guoqingri juhui gaiming guojiari chongbai' ('National Day celebrations renamed National Day service'), Ming Pao Daily, 1 July 1996.

7 The questionnaire issued in the 'Road to Reunification Forum for Lay Christians' was the same as the one issued in the first 'Road to Reunification' forum (see note 27). The results were shown as follows:

\begin{tabular}{ccccccc}
\hline Statement & $\begin{array}{c}\text { Strongly } \\
\text { disagree }\end{array}$ & Disagree & $\begin{array}{c}\text { No comment/ } \\
\text { not applicable }\end{array}$ & Agree & $\begin{array}{c}\text { Strongly } \\
\text { agree }\end{array}$ & $\begin{array}{c}\text { Not } \\
\text { answered }\end{array}$ \\
\hline Q.1 & 45 & 29 & 31 & 54 & 38 & 5 \\
Q.2 & 58 & 33 & 31 & 40 & 31 & 3 \\
Q.3 & 49 & 35 & 38 & 40 & 30 & 10 \\
\hline
\end{tabular}


Source: Cheung Yuk Wan et al., 'Jiaohui guoqing ...'.

72 Leung Wai Fung, 'Woshi zhongguo guomin? - gelie zhitong' ('Am I Chinese? - the agony of alienation'), Ming Pao Daily, 9 July 1996.

${ }^{73}$ Chenmoren (The Silent One), 'Zheshi wo dui guojiari chongbai de lichang' ('My position regarding the National Day service'), Christian Times, no. 466, 4 August 1996, p. 8.

${ }^{74}$ Zhi Cheng (Sincerity), 'Guojia zhudaori jiao shiyi' ('A national rogation day would be more appropriate'), Christian Times, no. 469, 25 August 1996, p. 8.

75 Chan $\mathrm{Yi} \mathrm{Li}$, 'Cong jidutu shuangchong shenfen kan guoqing wenti' ('The twofold identity of Christians and National Day celebrations'), Christian Times, no. 470, 7 July 1996, p. 8.

76 Chan Ka Wai, op. cit., see note 29.

77 Raymond Fung, 'Kansi caoshou' ('Virtues in vain'), Christian Times, no. 463, 14 July 1996, p. 10.

78 ibid.

79 For lay Christians' views on the timing of the celebrations, see Chenmoren, 'Zheshi wo dui ...'; Pingxintu (A Lay Believer), 'Qing yuanling women de lengmo' ('Please excuse our indifference'), Christian Times, no. 474, 29 September 1996, p. 9.

80 Lo Ping Cheung, 'Shiyi de shuangchong hanyi' ('The twofold implications of 1 October'), Christian Times, no. 464, 21 July 1996, p. 7.

81 Kang Phee Seng, 'Huiqui lishang de jiji yu weiji' ('To be or not to be on the road to reunification'), Christian Times, no. 465, 28 July 1996, p. 8.

82 Raymond Fung, 'Business as usual', Christian Times, no. 471, 9 August 1996, p. 10.

${ }^{83}$ Raymond Fung, 'Yichang gaodu gongming de xi' ('A highly symphonic show'), Christian Times, no. 462, 7 July 1996, p. 10.

8t $\mathrm{Ng}$ Kwai Heng, 'Dui jidujiao zifa chouzu guoqing huodong de fansi' ('Reflections on the National Day celebration incident of the Christian community'), Hong Kong Economic Journal, 25 June 1996.

8s Lau Siu Lun, 'Ping jidujiao guoqing bianlun' ('Comments on the Christian National Day celebration debate'), Sing Tao Daily, 19 August 1996.

86 'Hong Kong Alliance in Support of the Patriotic Movement in China' is a political alliance formed after the Tiananmen prodemocracy movement in 1989. It is regarded by the Chinese government as a 'rebellious' group.

${ }^{87} \mathrm{Ng}$ Kwai Heng, 'Dui jidujiao ...'.

${ }_{88}$ Lau Siu Lun, 'Ping jidujiao ...'

89 This is particularly relevant to a topic on which sociological studies have recently focused, namely the relationship between religion and identity in the context of contemporary China and Taiwan. See Stephen Feuchtwang, 'Local religion and village identity', in Tao Tao Liu and David Faure (eds), Unity and Diversity: Local Cultures and Identity in China (Hong Kong University Press, Hong Kong, 1996), pp. 161-76; Paul Steven Sangren, 'Renleixue yu taiwan de rentong zhengzhi: lun defang zongjiao de yingxiang' ('Anthropology and identity politics in Taiwan: review of the impact of local religion'), Hong Kong Social Science Journal, no. 11, 1998, pp. 41-72; and Robert P. Weller, 'Zongjiao yu "xin taiwan rentong": yixie chubu sisuo' ('Religion and "new Taiwanese identity": preliminary investigations'), ibid., pp. 73-82.

90 Luk Fai, for example, said: 'The church is basically a unity in diversity, just as a body has different parts that are gifted in different ways. Therefore it is normal to have different opinions within the church. ... Christians should constantly pray that the Christian community will witness the love of Christ in unity.' Luk Fai, 'Huigui lushang. ...' Kung Lap Yan wrote: 'From one point of view, the wounds inflicted by the 4 June Incident have yet to be healed. But, more fundamentally, what does the nature of the church have to do with National Day celebrations? From a strategic point of view, this may not be conducive to agreement within the church. Instead we should engage in more discussions and do more analyses. We should learn to listen to and show respect and appreciation for the views of others, so that we will always bear in mind the spirit of unity in diversity.' See Kung Lap Yan, 'Jidutu chouban. ...' Leung Wai Fung wrote: 'May I make a suggestion to 
the sponsors: maybe you should wait, since most lay members and clergy are not yet ready for this. You should not therefore insist on going your own way, because most important of all, you should match the pace of your fellow believers for the sake of unity.' Leung Wai Fung, 'Woshi zhongguo ...'.

91 Studies on the American Methodist Church by James R. Wood and Jon P. Bloch have produced similar findings. See Wood and Bloch, op. cit.

92 Stephen Hart has indicated that the cultural code has an extremely significant impact on social movements, and points to the close interrelatedness between American religions and the political culture of local social movements. A question relating to the Calhoun theory is implicit here: does the solidarity of a civil society require more subtle cultural ideas than rational-critical discourses as the foundation for social movements? See Stephen Hart, 'The cultural dimension of social movements: a theoretical reassessment and literature review', Sociology of Religion, vol. 57, no. 1, 1996, pp. 87-100. 